\title{
Interactive Outcome of Dates of Sowing and Genotypes Over Environments on Root Yield and Quality Attributes in Sugarbeet (Beta vulgaris L.)
}

\author{
Navdeep Singh ${ }^{1}, \mathrm{~K} S$ Thind ${ }^{2}$ and Gulzar Singh Sanghera ${ }^{3 *}$ \\ ${ }^{1}$ Department of Plant Breeding and Genetics, Punjab Agricultural University, Ludhiana, Punjab, India \\ ${ }^{2}$ Directorate of Research, PAU, Ludhiana, Punjab, India \\ ${ }^{3}$ PAU Regional Research Station, Kapurthala, Punjab, India \\ *Corresponding Author: Gulzar Singh Sanghera, PAU Regional Research Station, Kapurthala, Punjab, India.
}

Received: August 20, 2019; Published: September 24, 2019

DOI: 10.31080/ASAG.2019.03.0663

\begin{abstract}
This study was conducted to assess the effects of different dates of sowing and genotypes on root yield and quality traits in sugar beet. The experimental material consisted of five sugarbeet genotypes viz; Calixta, Magnolia, Cauvery, Shubra and Indus grown in randomized block design with plot size of 6 rows of $6 \mathrm{~m}$ x $0.75 \mathrm{~m}$ over nine environments involving three sowing dates at three locations namely Ludhiana, Kapurthala and Faridkot, Punjab during Rabi season 2014 - 2015. Analysis of variance revealed significant differences among locations for the traits like initiation of root swelling, number of leaves at maximum growth stage, root length, root diameter, root fresh weight, root dry weight at harvest, whole plant weight, root yield, sucrose (\%), juice purity (\%) and sugar yield. Date of sowing showed significant effect on traits like initiation of root swelling (DAS), whole plant weight, root dry weight, root yield and sugar yield. 30th October sowing had highest root fresh weight while sucrose (\%) was highest on 15th November sowing. Similarly, the effect of locations was significant for number of leaves at maximum growth and Brix (\%). Kapurthala location was found earliest to initiate root swelling (DAS) and possessed highest mean value for root length, sucrose (\%), juice purity root yield and sugar yield. Highest means of dry root weight, sucrose (\%) was recorded by genotype Calixta while genotype Magnolia recorded highest juice purity (\%). The highest means of whole plant weight, root fresh weight and root dry weight was recorded at Faridkot on 15th October sowing date. Kapurthala was adjudged the best location for sugarbeet cultivation followed by Faridkot. 15th October was ideal sowing date for sugarbeet cultivation as it recorded earlier root swelling, higher root yield and higher sugar yield over locations under Punjab conditions.
\end{abstract}

Keywords: Sugarbeet; Growth Parameters; Root Yield; Sugar Yield; Sucrose (\%); Juice Analysis

\section{Introduction}

Sugarbeet (Beta vulgaris L.) belongs to the family Chenopodiaceae, is considered as the second important sugar crop all over the world after sugar cane. Nearly $70 \%$ of sugar produced in the world is from sugarcane and about $30 \%$ of sugar is produced from sugarbeet [1]. It is a biennial, cross pollinated plant commercially grown for sugar production, especially in temperate countries. Sugarbeet cultivation in India was introduced in 1914 while its commercial cultivation started in Sriganganagar district of Rajasthan (India) in 1968 after producing first beet sugar by Sriganganagar sugar mill. Punjab state has favourable climatic conditions where sugarbeet can be successfully cultivated. Though, it is a short season Rabi crop (sown in October-November and harvested in April-May), its yields are equivalent to that of sugarcane with comparable sucrose content (16 - 22\%) [2]. Additional advantage of its cultivation is that it matures is ready to harvest during the period, when the cane-crushing season is already over. Thus, supply of sugarbeet can extend the crushing season of sugar mills in Punjab state.

Sugarbeet crop growth is influenced by a multitude of factors such as climate, soil texture, nutrient availability, occurrence of pests and diseases and their interactions. It has been demonstrated that the yield potential of sugarbeet depends primarily on site and year effects, whereas the influence of agronomic practices is much lower. Effect of the site can be attributed mainly to its constant characteristics of soil and climate and their interactions. He further suggested that effect of the year reflects the weather conditions during the vegetation period, which directly influence plant growth and the dates of sowing and harvest and thus, the length of the growing season. In another study, the impact of weather on the growth of agricultural crops has been reported to be essential for optimizing agronomic measures [3]. The genotype $\mathrm{x}$ environment interaction ( $\mathrm{G} \times \mathrm{E}$ ) is very important for plant breeding, mainly concerning the development of improved and superior genotypes [4]. Environmental factors cannot be controlled but may be adjusted to a positive direction for good crop performances in terms of yield and plant characters through sowing in optimum time. Campbell and Kern [5] determined the presence and magnitude of cultivar $\mathrm{x}$ environment interactions for yield and quality data from five locations and four years in sugarbeet and reported that cultivar $\mathrm{x}$ location interaction for root yield ranked cultivars differently during testing at all locations. 
In addition to location or environment, date of sowing is also a very important variable for determination of appropriate growth period required for proper growth and productivity. Sowing time for a crop is a non-monetary input but plays a significant role in increasing the yield of sugarbeet. Therefore, identification of genotypes/variety and specific sowing date are essential for obtaining economic yield of the crop. Thus, planting sugarbeet on suitable date according to environmental conditions of region is best method to maximize sugarbeet yield and quality. So, it is crucial to find out a genotype specific optimum sowing date with a view to obtain maximum root yield in sugarbeet. As a matter of example, Amin., et al. [6] had reported that early sowing of sugarbeet during October month gave higher beet root yield as well as higher sucrose content.

By considering the above facts, the present research work was designed to find out the magnitude of effect of different locations, dates of sowing and genotypes on yield and quality attributes in sugarbeet in Punjab representing sub-tropical conditions.

\section{Materials and Methods}

The experiments of this study were conducted at three locations viz; Punjab Agricultural University Ludhiana, Research Station Faridkot and Regional Research Station Kapurthala during the Rabi season of 2014-15 using five sugarbeet genotypes namely Calixta, Magnolia, Cauvery, Shubra and Indus with three dates of sowings (15 ${ }^{\text {th }}$ October, $15^{\text {th }}$ November and 30th November). The experiment was laid out in split-split plot design with three replications with each genotype in six rows of $6 \mathrm{~m}$ length with inter-row spacing 75 $\mathrm{cm}$ and intra-row spacing of $15 \mathrm{~cm}$. Thinning was done to keep one plant per hill after 7 days of germination. Irrigation frequency was enough to prevent significant plant water stress. The data were recorded on five representative plants of each genotype (leaving the border rows) at each sampling and averaged to per plant in each replication in all the nine environments for different characteristics viz; germination (\%), initiation of root swelling (DAS), number of leaves at root swelling, number of leaves maximum growth stage, root length $(\mathrm{cm})$, root diameter $(\mathrm{cm})$, top fresh weight $(\mathrm{kg})$, root fresh weight $(\mathrm{kg})$, root dry weight $(\mathrm{kg})$, whole plant weight $(\mathrm{kg})$, root yield ( $\mathrm{t} / \mathrm{ha}$ ) and quality characters Brix (\%), sucrose (\%), juice purity (\%) and sugar yield (t/ha).

\section{Statistical analysis}

Data recorded for the above traits were subjected to statistical analysis as per the analysis of variance for split-split plot design using SAS software ver. 9.2 [7] and interpretations were made accordingly.

\section{Results and Discussion}

Analysis of variance revealed that traits like root fresh weight, root dry weight, whole plant weight, sucrose (\%), juice purity and sugar yield were significantly effected by all the sources of variation i.e. location, date of sowing and genotypes (Table 1). Mean sum of squares for interactive effect between locations and dates of sowing were found significant for various traits in sugarbeet like initiation of root swelling, number of leaves at maximum growth stage, root diameter, top fresh weight, root fresh weight, root dry weight, whole plant weight, root yield and quality traits like sucrose (\%), juice purity and sugar yield. While interaction between dates of sowing and genotypes were significant for root dry weight, root yield, sucrose (\%) and sugar yield. Interactions based on location and genotypes were found to be significant for initiation of root swelling, root diameter, whole plant weight, sucrose (\%) and juice purity. Only yield attributes like germination (\%), root fresh weight and root dry weight showed significant effects for threeway interactions among locations, dates of sowing and genotypes indicating no variable effect on quality parameters. These findings are in accord with the results reported by Winner [8] and Al-Jbawi and Entessar [9] in sugarbeet.

Germination forms the basis for optimum plant population necessary for securing better yield of any crop. Though there were no significant differences for germination due to different factors and their two way interactions, however, the genotype Indus recorded high germination (90\%) on $15^{\text {th }}$ November sowing at Ludhiana, followed by Calixta (89.33\%) at Kapurthala. Initiation of root swelling determines the earliness in beet root metabolites accumulation. The root swelling initiation among genotypes ranged from 34.89 to 37.04 with a mean of 35.82 days after sowing (DAS). The genotype Calixta was the earliest while Indus was the last to initiate the root swelling (Table 2). The location Faridkot was earlier (35.71 DAS) than Kapurthala and Ludhiana to initiate the root swelling. However, interactive effect among locations and dates of sowing revealed that $30^{\text {th }}$ October sowing was the earliest (35.70 DAS) in root swelling initiation over all the locations (Table 3 ). The results obtained also finds a mention by Lee., et al. [10], Ghonema [11] and Abd EL-Gawad., et al. [12] in sugarbeet.

The number of leaves at initiation of root swelling stage among different sugarbeet genotypes ranged from 6.11 to 7.33. The maximum number of leaves was recorded in Indus (7.33) genotype closely followed by Calixta (7.00) (Table 2). Significant differences for location and interaction between location and date of sowing were recorded for number of leaves at maximum growth stage (Table 1) indicating that date of sowing may be adjusted depending upon the location. The number of leaves at maximum growth stage over locations showed better plant growth at Kapurthala (19.73) followed by Ludhiana (17.57) (Table 2). The trait was greatly influenced by the location and date of sowing in combination. Among the dates of sowing tested, 15 October recorded the highest number of leaves at maximum growth stage (18.60) over locations. Root length, an important trait in sugarbeet was found maximum at Kapurthala $(29.20 \mathrm{~cm})$ followed at Ludhiana $(28.07 \mathrm{~cm})$ indicating the differential response of locations for the expression of this trait (Table 2). Among the dates of sowing, $15^{\text {th }}$ October exhibited better performance for this trait having a root length of $29.43 \mathrm{~cm}$. The effects of location and date of sowing on root length in sugarbeet have been reported by Abo El-Ghait [13]. The significant effect of locations, genotypes, location $\mathrm{x}$ date of sowing and location $\mathrm{x}$ genotypic interactions on manifestation of root diameter in sugarbeet was evident from the variable response of this trait in different environments. It ranged from $8.98 \mathrm{~cm}$ at Ludhiana to $9.94 \mathrm{~cm}$ 


\begin{tabular}{|c|c|c|c|c|c|c|c|c|c|}
\hline \multicolumn{3}{|c|}{ Source of Variation } & \multirow{2}{*}{$\begin{array}{c}\text { Location (L) } \\
2\end{array}$} & \multirow{2}{*}{$\begin{array}{c}\text { Date of Sowing (D) } \\
2\end{array}$} & \multirow{2}{*}{$\begin{array}{c}\text { Genotypes (G) } \\
4\end{array}$} & \multirow{2}{*}{$\begin{array}{c}\text { L X D } \\
4\end{array}$} & \multirow{2}{*}{$\frac{\text { D X G }}{8}$} & \multirow{2}{*}{$\begin{array}{c}\text { L X G } \\
8\end{array}$} & \multirow{2}{*}{$\frac{\text { L X D X G }}{16}$} \\
\hline S. No. & Traits & d.f. & & & & & & & \\
\hline 1 & \multicolumn{2}{|c|}{ Germination (\%) } & 8.60 & 1.40 & 29.21 & 6.07 & 12.65 & 17.41 & $22.72^{*}$ \\
\hline 2 & \multicolumn{2}{|c|}{$\begin{array}{l}\text { Initiation of root } \\
\text { swelling (DAS) }\end{array}$} & $1.09^{* *}$ & $2.82^{* *}$ & 19.80 & $1.78^{* *}$ & 7.89 & $3.49^{*}$ & 2.95 \\
\hline 3 & \multicolumn{2}{|c|}{$\begin{array}{l}\text { No. of leaves at root } \\
\text { swelling stage }\end{array}$} & 1.09 & 0.47 & $6.80^{*}$ & 1.36 & 1.60 & 3.12 & 1.57 \\
\hline 4 & \multicolumn{2}{|c|}{$\begin{array}{l}\text { No. of leaves at maxi- } \\
\text { mum growth stage }\end{array}$} & $86.94 *$ & 39.21 & 7.92 & $23.12^{*}$ & 4.37 & 7.47 & 8.05 \\
\hline 5 & \multicolumn{2}{|c|}{ Root length (cm) } & $53.38^{*}$ & $60.62^{*}$ & 5.69 & 6.95 & 6.72 & 5.65 & 5.28 \\
\hline 6 & \multicolumn{2}{|c|}{ Root diameter $(\mathrm{cm})$} & $38.57^{*}$ & 1.79 & $9.60^{*}$ & $27.61^{* *}$ & 1.94 & $9.74 * *$ & 2.55 \\
\hline 7 & \multicolumn{2}{|c|}{ Top fresh weight (kg) } & $14.80^{*}$ & 0.15 & 0.27 & $0.58^{* *}$ & 0.10 & 0.21 & 0.12 \\
\hline 8 & \multicolumn{2}{|c|}{$\begin{array}{l}\text { Root fresh weight } \\
(\mathrm{kg})\end{array}$} & $208.99^{* *}$ & $30.94^{* *}$ & $2.37^{* *}$ & $13.79^{* *}$ & 0.48 & 0.61 & $0.91^{* *}$ \\
\hline 9 & \multicolumn{2}{|c|}{ Root dry weight $(\mathrm{kg})$} & $11.49^{* *}$ & $0.72^{* *}$ & $0.51^{* *}$ & $0.28^{* *}$ & $0.08^{* *}$ & $0.28^{* *}$ & $0.12^{* *}$ \\
\hline 10 & \multicolumn{2}{|c|}{$\begin{array}{l}\text { Whole plant weight } \\
(\mathrm{kg})\end{array}$} & $319.47^{* *}$ & $22.63^{* *}$ & 2.27 & $13.03^{* *}$ & 1.19 & $2.36^{* *}$ & 0.68 \\
\hline 11 & \multicolumn{2}{|c|}{ Root yield (t/ha) } & $1235.08^{* *}$ & $5605.05^{* *}$ & 1241.60* & 1462.78* & $522.07^{*}$ & 325.93 & 322.23 \\
\hline 12 & \multicolumn{2}{|c|}{ Brix (\%) } & 80.32 & 19.07 & 5.89 & 3.66 & 1.78 & 3.89 & 2.38 \\
\hline 13 & \multicolumn{2}{|c|}{ Sucrose (\%) } & $43.09^{* *}$ & $30.64^{* *}$ & $5.80^{* *}$ & $13.03^{* *}$ & $2.08^{*}$ & $3.50^{* *}$ & 2.81 \\
\hline 14 & \multicolumn{2}{|c|}{ Juice purity (\%) } & $67.94^{* *}$ & $123.89 * *$ & $29.94^{* *}$ & $82.77^{*}$ & 23.97 & $55.65^{*}$ & 29.44 \\
\hline 15 & \multicolumn{2}{|c|}{ Sugar yield (t/ha) } & $47.90^{* *}$ & $71.21^{* *}$ & 7.72 & $55.55^{* *}$ & $13.17^{* *}$ & 3.33 & 6.67 \\
\hline
\end{tabular}

Table 1: Mean sum of squares for locations, date of sowing, genotypes and their interactions on different traits in sugarbeet.

\begin{tabular}{|c|c|c|c|c|c|c|c|c|c|c|c|c|c|c|}
\hline \multirow{2}{*}{ : } & \multicolumn{4}{|c|}{ 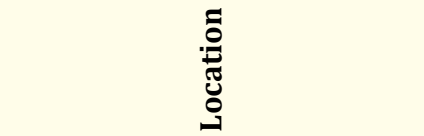 } & \multicolumn{4}{|c|}{ 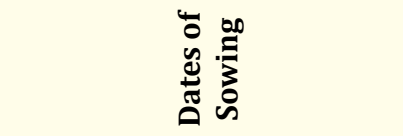 } & \multicolumn{6}{|c|}{ 爮 } \\
\hline & 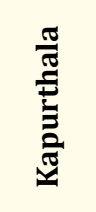 & & 范 & 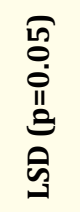 & $\begin{array}{l}\overleftarrow{U} \\
\text { ம் } \\
\text { ம் }\end{array}$ & $\begin{array}{l}\overleftarrow{U} \\
0 \\
0 \\
\dot{n}\end{array}$ & $\begin{array}{l}z \\
z \\
\text { L̇ } \\
7\end{array}$ & $\begin{array}{l}\text { In } \\
0 \\
0 \\
\text { II } \\
\text { ق } \\
\text { ڤ్ }\end{array}$ & 预 & 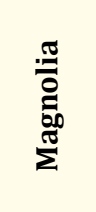 & $\sum_{0}^{2}$ & $\frac{\pi}{\frac{2}{3}}$ & $\stackrel{\mathscr{e}}{\Xi}$ & $\begin{array}{l}\text { L2 } \\
0 \\
0 \\
\text { II } \\
\text { ق } \\
\text { 气 }\end{array}$ \\
\hline Germination (\%) & 86.80 & 86.46 & 85.93 & N.S & 86.53 & 86.46 & 86.2 & N.S & 86.89 & 84.70 & 87.33 & 86.15 & 86.93 & N.S \\
\hline $\begin{array}{l}\text { Initiation of root } \\
\text { swelling (DAS) }\end{array}$ & 36.00 & 35.75 & 35.71 & 0.21 & 36.66 & 35.68 & 34.11 & 0.21 & 34.89 & 35.15 & 36.19 & 35.85 & 37.04 & N.S \\
\hline $\begin{array}{l}\text { No. of leaves at root } \\
\text { swelling }\end{array}$ & 6.61 & 6.55 & 6.84 & N.S & 6.75 & 6.75 & 6.55 & N.S & 7.00 & 6.30 & 6.11 & 6.59 & 7.33 & 0.62 \\
\hline $\begin{array}{l}\text { No of leaves at } \\
\text { maximum growth }\end{array}$ & 19.53 & 17.57 & 16.84 & 0.74 & 18.62 & 18.44 & 16.91 & N.S & 17.96 & 17.22 & 18.48 & 17.74 & 18.52 & N.S \\
\hline Root length (cm) & 29.20 & 28.07 & 27.02 & 1.10 & 29.43 & 27.40 & 27.45 & 0.61 & 28.28 & 27.72 & 28.80 & 28.02 & 30.84 & N.S \\
\hline Root diameter $(\mathrm{cm})$ & 9.94 & 8.98 & 9.82 & 0.70 & 9.65 & 9.64 & 9.45 & N.S & 9.98 & 9.57 & 9.44 & 9.11 & 9.82 & 0.30 \\
\hline $\begin{array}{l}\text { Top fresh weight } \\
(\mathrm{kg})\end{array}$ & 1.27 & 0.38 & 1.45 & 0.36 & 1.08 & 1.04 & 0.97 & N.S & 0.96 & 1.12 & 1.16 & 1.02 & 0.92 & N.S \\
\hline $\begin{array}{l}\text { Root fresh weight } \\
\text { (kg) }\end{array}$ & 3.11 & 0.94 & 5.25 & 0.49 & 3.00 & 3.14 & 2.26 & 0.49 & 2.93 & 3.26 & 3.43 & 2.69 & 3.24 & 0.41 \\
\hline $\begin{array}{l}\text { Root dry weight } \\
\text { (kg) }\end{array}$ & 0.88 & 0.21 & 1.20 & 0.25 & 0.90 & 0.74 & 0.66 & 0.25 & 0.92 & 0.86 & 0.81 & 0.65 & 0.62 & 0.21 \\
\hline $\begin{array}{l}\text { Whole plant weight } \\
\text { (kg) }\end{array}$ & 5.22 & 1.53 & 6.72 & 0.64 & 5.25 & 4.35 & 3.85 & 0.64 & 4.55 & 4.47 & 4.85 & 4.04 & 4.51 & N.S \\
\hline Root yield (t/ha) & 81.48 & 69.48 & 76.14 & 3.52 & 88.08 & 73.13 & 66.25 & 3.52 & 80.86 & 73.48 & 75.48 & 75.68 & 73.62 & 1.44 \\
\hline Brix (\%) & 18.83 & 16.17 & 17.66 & N.S & 16.81 & 17.99 & 17.86 & N.S & 17.71 & 16.73 & 17.73 & 17.81 & 17.82 & N.S \\
\hline Sucrose (\%) & 16.20 & 14.28 & 14.91 & 0.63 & 14.19 & 14.47 & 15.73 & 0.63 & 15.43 & 14.31 & 15.39 & 15.31 & 15.23 & 0.21 \\
\hline Juice purity (\%) & 85.97 & 83.55 & 84.41 & 1.64 & 82.73 & 85.57 & 85.63 & 1.64 & 83.01 & 84.22 & 85.67 & 85.53 & 84.71 & 1.37 \\
\hline Sugar yield (t/ha) & 12.25 & 10.27 & 10.73 & 0.99 & 12.53 & 10.52 & 10.22 & 0.99 & 11.96 & 10.59 & 11.17 & 10.96 & 10.76 & N.S \\
\hline
\end{tabular}

Table 2: Effect of locations, dates of sowing and genotypes on growth, yield and quality traits in sugarbeet. 


\begin{tabular}{|c|c|c|c|c|c|c|c|c|}
\hline \multirow{2}{*}{ Traits } & \multirow{2}{*}{ DOS (D) } & \multicolumn{4}{|c|}{ Locations (L) } & \multicolumn{3}{|c|}{$C D(P=0.05)$} \\
\hline & & Kapurthala & Ludhiana & Faridkot & Mean & $\mathbf{L}$ & D & L X D \\
\hline \multirow{4}{*}{ Initiation of root swelling (DAS) } & $15-$-Oct & 36.20 & 35.33 & 35.47 & 36.20 & \multirow[t]{4}{*}{0.81} & \multirow[t]{4}{*}{0.78} & \multirow[t]{4}{*}{0.91} \\
\hline & 30-Oct & 35.87 & 35.53 & 35.67 & 35.70 & & & \\
\hline & $15-$ Nov & 35.93 & 36.40 & 36.00 & 36.10 & & & \\
\hline & Mean & 36.00 & 36.00 & 36.00 & & & & \\
\hline \multirow[t]{4}{*}{ No. of leaves at maximum growth } & $15-0 c t$ & 21.13 & 17.60 & 17.07 & 18.60 & \multirow[t]{4}{*}{1.07} & \multirow[t]{4}{*}{ N.S } & \multirow[t]{4}{*}{1.2} \\
\hline & 30-Oct & 20.60 & 18.07 & 16.67 & 18.40 & & & \\
\hline & 15-Nov & 16.87 & 17.07 & 16.80 & 16.90 & & & \\
\hline & Mean & 19.50 & 17.60 & 16.80 & & & & \\
\hline \multirow[t]{4}{*}{ Root diameter $(\mathrm{cm})$} & 15-Oct & 10.28 & 8.10 & 10.58 & 9.94 & \multirow[t]{4}{*}{0.36} & \multirow[t]{4}{*}{ N.S } & \multirow[t]{4}{*}{0.40} \\
\hline & 30-Oct & 9.79 & 9.46 & 9.12 & 9.46 & & & \\
\hline & 15-Nov & 10.58 & 9.76 & 9.12 & 9.81 & & & \\
\hline & Mean & 9.94 & 8.98 & 9.81 & & & & \\
\hline \multirow[t]{4}{*}{ Top fresh weight (kg) } & 15 -Oct & 1.15 & 0.47 & 1.64 & 1.10 & \multirow[t]{4}{*}{0.36} & \multirow[t]{4}{*}{ N.S. } & \multirow[t]{4}{*}{0.10} \\
\hline & 30-Oct & 1.48 & 0.42 & 1.24 & 1.00 & & & \\
\hline & $15-$ Nov & 1.19 & 0.25 & 1.48 & 1.00 & & & \\
\hline & Mean & 1.30 & 0.40 & 1.50 & & & & \\
\hline \multirow[t]{4}{*}{ Root fresh weight (kg) } & 15-Oct & 4.16 & 1.16 & 6.43 & 3.90 & \multirow[t]{4}{*}{0.49} & 0.37 & 0.55 \\
\hline & 30-Oct & 4.00 & 0.96 & 4.49 & 3.20 & & & \\
\hline & $15-$ Nov & 1.19 & 0.73 & 4.86 & 2.30 & & & \\
\hline & Mean & 3.10 & 1.00 & 5.30 & & & & \\
\hline Root dry weight (kg) & 15-Oct & 0.98 & 0.27 & 1.48 & 0.91 & 0.25 & 0.18 & 0.28 \\
\hline & 30-Oct & 0.98 & 0.22 & 1.03 & 0.74 & & & \\
\hline & 15-Nov & 0.70 & 0.17 & 1.12 & 0.66 & & & \\
\hline & Mean & 0.89 & 0.22 & 1.21 & & & & \\
\hline Whole plant weight (kg) & 15-Oct & 6.23 & 1.46 & 8.07 & 5.30 & 0.64 & 0.58 & 0.71 \\
\hline & 30-Oct & 5.72 & 1.60 & 5.73 & 4.40 & & & \\
\hline & 15-Nov & 0.98 & 0.27 & 1.48 & 0.91 & & & \\
\hline & Mean & 0.98 & 0.27 & 1.48 & & & & \\
\hline Root yield (t/ha) & 15-Oct & 95.60 & 86.91 & 81.73 & 88.08 & 3.52 & 2.94 & 2.79 \\
\hline & 30-Oct & 69.98 & 69.00 & 80.43 & 73.14 & & & \\
\hline & 15-Nov & 79.96 & 52.53 & 66.27 & 66.25 & & & \\
\hline & Mean & 81.85 & 69.48 & 76.14 & & & & \\
\hline Sucrose (\%) & 15-Oct & 15.76 & 12.72 & 14.09 & 14.19 & 0.63 & 0.47 & 0.71 \\
\hline & 30-Oct & 16.43 & 14.08 & 15.91 & 15.47 & & & \\
\hline & 15-Nov & 16.43 & 16.04 & 14.73 & 15.73 & & & \\
\hline & Mean & 16.21 & 14.28 & 14.91 & & & & \\
\hline Juice purity (\%) & 15-Oct & 85.78 & 78.70 & 83.71 & 82.73 & 1.64 & 1.72 & 1.83 \\
\hline & $30-0 c t$ & 86.08 & 85.14 & 85.49 & 85.57 & & & \\
\hline & $15-$ Nov & 86.08 & 86.82 & 84.01 & 85.64 & & & \\
\hline & Mean & 85.98 & 83.55 & 84.40 & & & & \\
\hline Sugar yield (t/ha) & 15-Oct & 15.03 & 11.12 & 11.45 & 12.25 & 0.99 & 1.07 & 1.11 \\
\hline & $30-0 c t$ & 9.16 & 11.32 & 11.05 & 10.28 & & & \\
\hline & $15-N o v$ & 12.56 & 8.40 & 9.71 & 10.74 & & & \\
\hline & Mean & 12.25 & 10.28 & 10.74 & & & & \\
\hline
\end{tabular}

Table 3: Mean performance of traits exhibiting significant interactions between locations $x$ dates of sowing in sugarbeet.

at Kapurthala. Genotype Calixta recorded the maximum root diameter $(9.98 \mathrm{~cm})$ followed by Indus $(9.82 \mathrm{~cm})$ (Table 2). Of the dates under study, $15^{\text {th }}$ October sowing recorded the highest root diameter $(9.94 \mathrm{~cm})$ over locations. Among locations, Kapurthala was found better $(9.94 \mathrm{~cm})$ for root diameter across dates of sowing (Table 3). The mean root diameter among genotypes over locations ranged from $9.11 \mathrm{~cm}$ to $9.98 \mathrm{~cm}$ (Table 4). Al-Jbawi and Entessar [9] in his study also reported that genotype x location interaction exhibited significant effect on root diameter.
Root fresh weight trait was significantly affected by all the variable factors (Table 1). Maximum root fresh weight was recorded at Faridkot location $(5.25 \mathrm{~kg})$ and minimum at Ludhiana $(0.94 \mathrm{~kg})$ (Table 2). The $30^{\text {th }}$ October date of sowing recorded the highest root fresh weight $(3.14 \mathrm{~kg})$. Therefore, the dates from $15^{\text {th }}$ October to $30^{\text {th }}$ October would be ideal for sowing of sugarbeet in Punjab to get the better yields. The superiority of sowing sugarbeet on $30^{\text {th }}$ October with respect to root fresh weight may be due to the ideal weather conditions during early growth stages of plant that 
had not only maximum growth of roots but also rapid growth and formation a good canopy able to make efficient photosynthesis. These results are in harmony with those of earlier reported by different workers in sugarbeet [14-16]. Differential response of sugarbeet genotypes for root fresh weight has also been documented by Al-Jbawi and Entessar [9]. The interaction between locations and dates of sowing revealed that highest root fresh weight was observed on $15^{\text {th }}$ October sowing at Faridkot $(6.43 \mathrm{~kg}$ ) while the lowest was observed on $15^{\text {th }}$ November sowing at Ludhiana $(0.73$ $\mathrm{kg}$ ) (Table 3). Root dry weight parameter behaved exceptionally in a way that the individual factors viz; locations, dates of sowing and genotypes as well as all the interactions among them affected the trait significantly (Table 1). The maximum average root dry weight was obtained at Faridkot location $(1.20 \mathrm{~kg})$. The maximum value of dry root weight was recorded for $15^{\text {th }}$ October date of sowing $(0.90$ $\mathrm{kg}$ (Table 2). This observation paved the way for the fact that $15^{\text {th }}$ October date of sowing favours enhanced root dry weight. These results stood in agreement with those obtained by Badawi [14] and Kandil., et al. [16]. The maximum root dry weight was possessed by genotype Calixta $(0.92 \mathrm{~kg})$ while the minimum root dry weight was exhibited by genotype Indus ( $0.62 \mathrm{~kg})$. Theurer [17] and Hossain., et al [18] also reported the differential behaviour of date of sowing and genotype for root dry weight. The interaction between locations and dates of sowing was found to be significant for this trait which depicted that $15^{\text {th }}$ October date of sowing had the highest root dry weight ( $0.91 \mathrm{~kg}$ ) across all the locations (Table 3). Among locations, Faridkot was superior $(1.21 \mathrm{~kg}$ ) over Kapurthala and Ludhiana across the dates of sowing for root dry weight. The $15^{\text {th }}$ October date of sowing produced maximum root dry weight of 0.91 kg over the genotypes (Table 4). The mean performance of genotype Calixta was highest ( $0.91 \mathrm{~kg}$ ) followed by Magnolia $(0.85 \mathrm{~kg}$ ) across all the dates of sowing. The three-way interactions among sources of variation studied were found to be significant for root dry weight (Table 5). The $15^{\text {th }}$ October date of sowing resulted in highest root dry weight $(0.91 \mathrm{~kg})$ followed by $30^{\text {th }}$ October sowing $(0.74 \mathrm{~kg})$ over locations and genotypes. The mean performance of genotypes for this trait over locations and dates of sowing ranged from $0.13 \mathrm{~kg}$ to $1.63 \mathrm{~kg}$. Among the genotypes, Calixta recorded maximum root dry weight $(1.97 \mathrm{~kg})$ followed by Cauvery $(1.45$ $\mathrm{kg}$ ) across the locations and dates of sowing. Among the locations, Faridkot was outstanding for root dry weight $(1.48 \mathrm{~kg})$ while Ludhiana was lowest $(0.01 \mathrm{~kg})$. Whole plant weight had a gradual fall from $5.25 \mathrm{~kg}$ when sown on $15^{\text {th }}$ October sowing, to $4.35 \mathrm{~kg}$ on $30^{\text {th }}$ October sowing and $3.85 \mathrm{~kg}$ on $15^{\text {th }}$ November sowing, respectively (Table 2).

The mean whole plant weight for locations across genotypes ranged from $1.53 \mathrm{~kg}$ to $8.30 \mathrm{~kg}$. The maximum whole plant weight was recorded for $15^{\text {th }}$ October sowing $(8.07 \mathrm{~kg}$ ) at Faridkot (Table 3 ). The mean performance of genotypes for whole plant weight ranged from $4.52 \mathrm{~kg}$ to $5.38 \mathrm{~kg}$. The genotype Magnolia possessed the maximum whole plant weight of $9.13 \mathrm{~kg}$ at Faridkot followed by Indus ( $8.63 \mathrm{~kg}$ ) at Faridkot while the minimum whole plant weight was recorded by genotype Shubra at Ludhiana (1.41 kg) (Table 4).
The trait of economic importance i.e. root yield indicated the significant effects of locations, dates of sowing, genotypes and twoway interactions among the variables (Table 1). It is evident from data presented in table 2 that the best location for sugarbeet cultivation was found to be Kapurthala having root yield of $81.48 \mathrm{t} /$ ha. The highly significant effects of locations on root yield in sugarbeet have also been reported in earlier studies $[9,19,20]$. They showed that locations had a marked influence on manifestation of root yield in sugarbeet. Among dates of sowing, $15^{\text {th }}$ October was ascertained to be most suitable to obtain high root yield (88.08 $\mathrm{t} / \mathrm{ha}$ ). The interactions among locations and genotypes indicated that location Kapurthala had highest root yield of 95.60 t/ha on $15^{\text {th }}$ October sowing while Ludhiana exhibited lowest root yield of $52.53 \mathrm{t} /$ ha on $15^{\text {th }}$ November sowing (Table 4 ). The effect of interaction between sowing dates and genotypes was in such a way that genotype Cauvery when sown on $15^{\text {th }}$ October gave highest root yield (102.08 t/ha). Contrarily, lowest root yield was accompanied with $15^{\text {th }}$ November date of sowing (Table 4). These results showing differential behaviour of locations, dates of sowing and genotypes and their interactions in sugarbeet are in agreement with those reported by various workers [11,14-16,21-23].

To start with the quality traits, Brix (\%) is one of the most obvious physio-biochemical traits in sugarbeet. Mean sum of squares among all the sources of variation and all the interactions were found to be non-differentiating for this trait. Sucrose (\%), another important quality trait was influenced significantly by locations, dates of sowing, genotypes and all the two-way interactions (Table 1). The location Kapurthala recorded maximum sucrose (16.20\%). However, among dates of sowing, $15^{\text {th }}$ November sown sugarbeet showed maximum sucrose content $(15.73 \%)$ followed by $30^{\text {th }}$ October (14.47\%) (Table 2). These findings are exactly antagonistic to those found for root yield in sugarbeet, in such a way that yield and quality attributes are inversely related with each other regarding sowing time. Therefore, it could be inferred that early sowing of sugarbeet resulted in low sucrose accumulation while delayed sowing showed promising results for enhancement of sucrose (\%) in sugarbeet. These results are in confirmation with earlier studies by Badawi [14], Ghonema [11] and Kandil., et al. [16]. The interactive effects among locations and dates of sowing revealed that mean sucrose (\%) was highest at location Kapurthala (16.21\%) over different dates of sowing while it was lowest for Ludhiana (14.28\%) (Table 3). In context of interaction between locations and genotypes, the location Faridkot recorded the highest sucrose $(16.36 \%)$ over genotypes. The genotype Shubra yielded the maximum sucrose (16.69\%) closely followed by Calixta (16.38\%) across all the locations (Table 4).

Regarding juice purity (\%), all the locations were at par for this trait ranging from $83.55 \%$ to $85.97 \%$. Delayed sowing of sugarbeet on $15^{\text {th }}$ November favoured the juice purity than earlier sowing. Among the genotypes tested, Cauvery recorded the highest juice purity (85.67\%) followed by Shubra (85.53\%). These findings are acceptable with those supported by Leilah and Naser [24], Ghonema [11] and Abo-Salama and EL-Sayiad [23]. The significance 


\begin{tabular}{|c|c|c|c|c|c|c|c|c|c|c|c|}
\hline \multicolumn{12}{|c|}{ Interactions between Dates of Sowing and Genotypes } \\
\hline \multirow{2}{*}{ Traits } & \multirow{2}{*}{ DOS (D) } & \multicolumn{6}{|c|}{ Genotypes (G) } & \multicolumn{4}{|c|}{ CD (P=0.05) } \\
\hline & & Calixta & Magnolia & Cauvery & Shubra & Indus & Mean & D & $\mathrm{C}$ & & D X G \\
\hline \multirow{4}{*}{$\begin{array}{l}\text { Root dry weight } \\
(\mathrm{kg})\end{array}$} & 15-Oct & 1.16 & 1.04 & 0.78 & 0.85 & 0.72 & 0.91 & \multirow[t]{4}{*}{0.25} & \multirow{4}{*}{\multicolumn{2}{|c|}{0.21}} & \multirow[t]{4}{*}{0.31} \\
\hline & 30-Oct & 0.90 & 0.81 & 0.8 & 0.54 & 0.59 & 0.75 & & & & \\
\hline & 15 -Nov & 0.66 & 0.69 & 0.7 & 0.52 & 0.47 & 0.61 & & & & \\
\hline & Mean & 0.91 & 0.85 & 0.7 & 0.64 & 0.62 & & & & & \\
\hline \multirow[t]{4}{*}{ Root yield (t/ha) } & $15-0 c t$ & 94.32 & 92.54 & 102. & 72.96 & 78.53 & 88.08 & \multirow[t]{4}{*}{3.52} & \multirow{4}{*}{\multicolumn{2}{|c|}{2.85}} & \multirow[t]{4}{*}{1.91} \\
\hline & $30-0 c t$ & 79.67 & 72.30 & 64.5 & 74.22 & 74.94 & 73.14 & & & & \\
\hline & 15-Nov & 68.23 & 71.76 & 60.5 & 63.46 & 67.26 & 66.25 & & & & \\
\hline & Mean & 80.74 & 78.87 & 75.7 & 70.21 & 73.58 & & & & & \\
\hline \multirow[t]{4}{*}{ Sucrose (\%) } & $15-0 c t$ & 13.56 & 14.67 & 14.7 & 13.51 & 13.87 & 13.95 & \multirow[t]{4}{*}{0.63} & \multirow{4}{*}{\multicolumn{2}{|c|}{0.21}} & 0.76 \\
\hline & $30-0 c t$ & 14.76 & 13.84 & 13. & 13.94 & 13.51 & 13.98 & & & & \\
\hline & $15-\mathrm{Nov}$ & 14.18 & 14.49 & 14. & 14.49 & 14.18 & 14.32 & & & & \\
\hline & Mean & 14.16 & 14.33 & 14. & 13.98 & 13.85 & & & & & \\
\hline Sugar yield (t/ha) & $15-0 \mathrm{ct}$ & 13.52 & 12.19 & 15. & 10.68 & 10.8 & 12.53 & 0.99 & $\mathrm{~N}$ & & 1.21 \\
\hline & $30-0 \mathrm{ct}$ & 11.95 & 10.18 & 9.1 & 10.52 & 10.78 & 10.51 & & & & \\
\hline & $15-\mathrm{Nov}$ & 10.69 & 11.04 & 9.4 & 10.09 & 9.91 & 10.22 & & & & \\
\hline & Mean & 12.05 & 11.14 & 11. & 10.43 & 10.49 & & & & & \\
\hline & & Inter & ractions bet & veen & notypes an & 1 Location & & & & & \\
\hline Traits & Location (L) & & & & enotypes (C & & & & & $(\mathrm{P}=0$. & 05) \\
\hline & & Calixta & Mag & olia & Cauvery & Shubra & Indus & Mean & $\mathbf{L}$ & G & L X G \\
\hline Initiation of root & Kapurthala & 29.23 & 28 & & 30.12 & 28.06 & 31.81 & 29.62 & 0.81 & N.S & N.S \\
\hline swelling (DAS) & Ludhiana & 35.00 & 35. & & 35.78 & 36.33 & 36.67 & 35.76 & & & \\
\hline & Faridkot & 35.56 & 35. & & 35.78 & 35.44 & 36.67 & 35.71 & & & \\
\hline & Mean & 33.26 & 33. & & 33.89 & 33.28 & 35.05 & & & & \\
\hline Root & Kapurthala & 10.15 & 9. & & 9.95 & 9.16 & 10.90 & 9.95 & 0.36 & N.S & 0.44 \\
\hline diameter $(\mathrm{cm})$ & Ludhiana & 9.77 & 8.8 & & 8.54 & 8.25 & 9.49 & 8.99 & & & \\
\hline & Faridkot & 10.02 & 10. & & 9.84 & 9.92 & 9.07 & 9.82 & & & \\
\hline & Mean & 9.98 & 9. & & 9.44 & 9.11 & 9.82 & & & & \\
\hline Root dry weight & Kapurthala & 0.86 & 1. & & 1.14 & 0.66 & 0.68 & 0.89 & 0.25 & 0.21 & 0.3 \\
\hline & Ludhiana & 0.23 & 0. & & 0.14 & 0.14 & 0.13 & 0.17 & & & \\
\hline & Faridkot & 1.63 & 1.2 & & 1.08 & 1.11 & 0.98 & 1.21 & & & \\
\hline & Mean & 0.90 & 0.8 & & 0.79 & 0.64 & 0.6 & & & & \\
\hline Whole plant & Kapurthala & 4.70 & $5.3^{3}$ & & 6.13 & 4.33 & 5.64 & 5.23 & 0.64 & 0.53 & 0.77 \\
\hline weight (kg) & Ludhiana & 1.46 & 1. & & 1.58 & 1.41 & 1.56 & 1.53 & & & \\
\hline & Faridkot & 7.39 & 9.1 & & 8.23 & 8.12 & 8.63 & 8.3 & & & \\
\hline & Mean & 4.52 & 5.3 & & 5.31 & 4.62 & 5.28 & & & & \\
\hline Sucrose (\%) & Kapurthala & 12.98 & 13 & & 13.11 & 13.29 & 12.58 & 13.02 & 0.63 & 0.21 & 0.76 \\
\hline & Ludhiana & 13.13 & 12. & & 13.40 & 11.97 & 12.93 & 12.86 & & & \\
\hline & Faridkot & 16.38 & 17 & & 15.71 & 16.69 & 16.04 & 16.36 & & & \\
\hline & Mean & 12.98 & 13 & & 13.11 & 13.29 & 12.58 & & & & \\
\hline Juice purity (\%) & Kapurthala & 82.86 & 79 & & 77.86 & 92.31 & 76.39 & 81.85 & 1.64 & 1.37 & 0.83 \\
\hline & Ludhiana & 81.69 & 77. & & 77.67 & 62.76 & 66.56 & 73.29 & & & \\
\hline & Faridkot & 77.67 & 79. & & 71.67 & 55.56 & 77.78 & 72.34 & & & \\
\hline & Mean & 80.74 & 78. & & 75.73 & 70.21 & 73.58 & & & & \\
\hline
\end{tabular}

Table 4: Mean performance of different traits for significant interactions among dates of sowing $\mathrm{x}$ genotypes and genotypes $\mathrm{x}$ locations in sugarbeet 


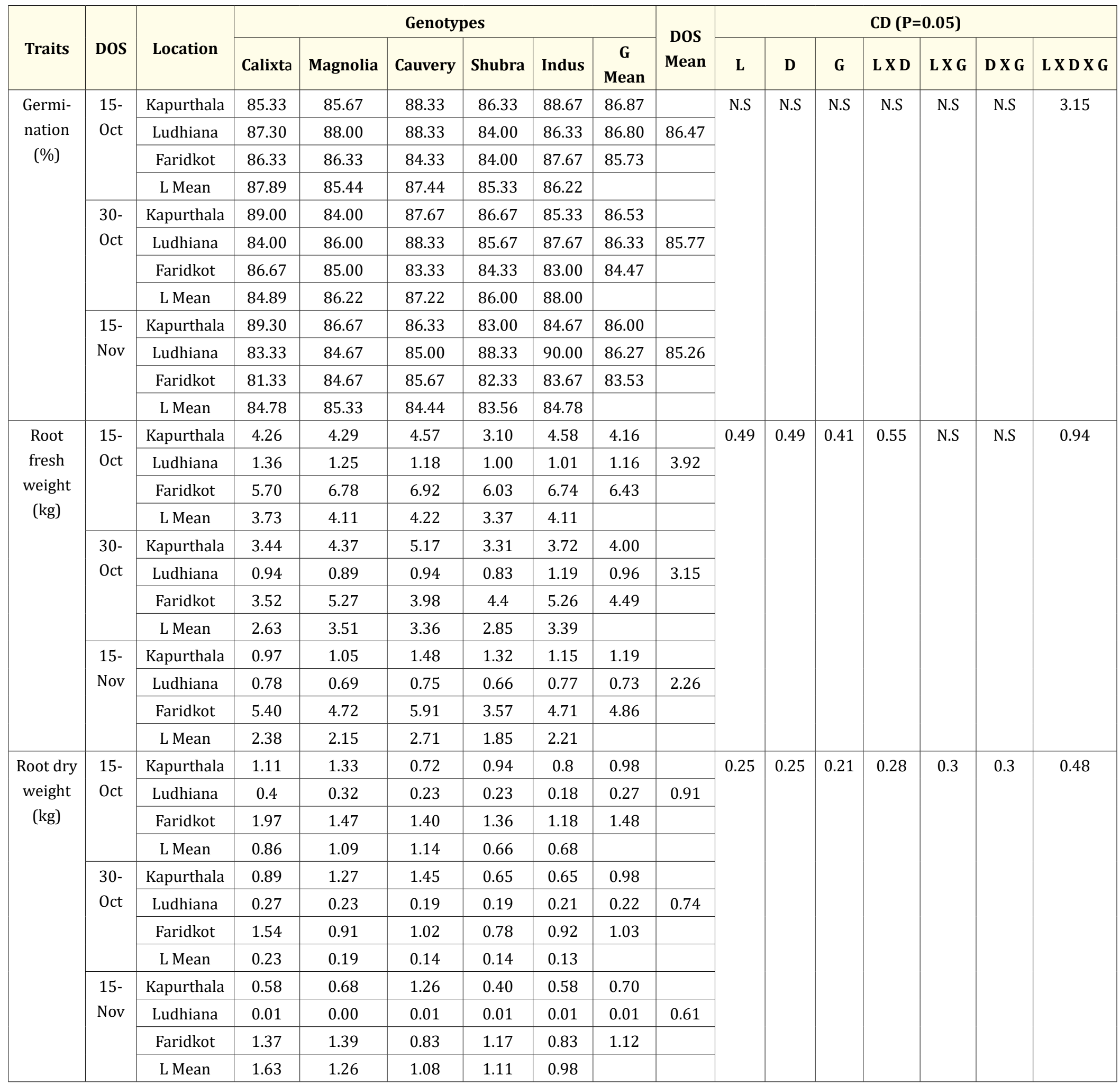

Table 5: Mean performance of traits for significant three-way interactions between locations, sowing dates and genotypes in sugarbeet.

of interaction between locations and genotypes depicted the effect of both of these factors on juice purity (\%). Genotype Shubra behaved both ways for juice purity in response to the locations and recorded the highest juice purity (92.31\%) at Kapurthala and the lowest (55.56\%) at Ludhiana.

Sugar yield ( $\mathrm{t} / \mathrm{ha}$ ) being the most imperative quality trait in sugarbeet requires prime emphasis. Among the locations, Kapurthala was the best location for sugar yield in sugarbeet where the highest sugar yield (12.20 t/ha) was recorded followed by Faridkot (10.73 t/ha) (Table 2). The favourable effects of sowing sugarbeet at Kapurthala on sugar yield may be ascribed to the seasonable environmental conditions during this period such as low temperature and relative humidity which allows rapid germination, establishment, vegetative growth, development and ripening. The highly significant effects of location on recoverable sugar yield reported here, are in line with those reported by Goto., et al. [19], Fronek., et al. [25], Kristek., et al. [20] and Al-Jbawi and Entessar [9], who showed that location had marked influence on recoverable sugar yield in sugarbeet. Out of different sowing dates examined, $15^{\text {th }}$ Octo- 
ber sowing proved to be highly beneficial to get maximum sugar yield of 12.53 (t/ha) followed by $30^{\text {th }}$ October sowing (10.52 t/ha). Kassaby and Leilah [21], Badawi., et al. [15], Ghonema [11], Abdou [22], Abo-Salama and EL-Sayiad [23] and Kandil., et al. [16]. Location Kapurthala had the highest sugar yield of $15.03(\mathrm{t} / \mathrm{ha})$ for $15^{\text {th }}$ October sowing (Table 3). The interaction for date of sowing and genotypes for sugar yield being significant revealed that the mean effects of dates of sowing over all the genotypes ranged from 10.22 (t/ha) to 12.53 (t/ha). However, genotype Calixta had the maximum sugar yield of $13.52(\mathrm{t} / \mathrm{ha})$ for $15^{\text {th }}$ October date of sowing (Table 4).

\section{Conclusion}

Most suitable location for sugarbeet cultivation to obtain higher yield and better quality could be zeroed in as Kapurthala followed by Faridkot. Among the dates of sowing, early sowing favours higher root yields while delayed sowing favours better quality output. So, a balanced approach has to be adopted to get promising yields with better quality in sugarbeet. Among the genotypes, Calixta was promising for various traits followed by Magnolia and Cauvery across the locations. Based on these findings, the ideal genotypes with respect to favourable locations and dates of sowing can be put to use for maximum exploitation of genetic potential with respect to yield and quality in sugarbeet in different regimes.

\section{Bibliography}

1. Amin G A., et al. "Root yield and quality of sugar beet (Beta vulgaris L.) in response to bio fertilizer and foliar application with micro-nutrients". World Applied Science Journal 27.11 (2013): 1385-1389.

2. Islam M S., et al. "Evaluation of tropical sugarbeet (Beta vulgaris L.) genotypes under Bangladesh condition". Bangla Journal Agricultural Research 37.4 (2012): 721-728.

3. Jones PD., et al. "Future climate impact on productivity of sugar beet (Beta vulgaris L.) in Europe". Climate Change 58.1-2 (2003): 93-108.

4. Allard R W and Bradshaw A D. "Implication of genotype environmental interactions in applied plant breeding". Crop Science 4 (1964): 503-507.

5. Campbell I G and Kern J J. "Cultivar x environment interactions in sugarbeet yield trials". Agronomy Journal 22.5 (1982): 932-35.

6. Amin M., et al. "Effect of date of sowing on yield and quality of sugarbeets". Pakistan Journal Agriculture Research 10 (1989): 30-33.

7. SAS Institute Inc. "Proceedings of the Twenty-Eighth Annual SAS $^{\circ}$ Users Group International Conference”. Cary, NC: SAS Institute Inc. (2003).
8. Winner C. "Site of growing and performance of sugar beet consideration on choosing varieties in relation to location". Zuckerindustrie 115 (1990): 34-38.

9. Al-Jbawi and M Entessar. "Performance of some sugar beet genotypes under different conditions”. M.Sc. thesis, Cairo University, Egypt (2000).

10. Lee G S., et al. "Effect of date of planting and nitrogen fertilization on growth components of sugarbeet". Journal of American Society of Sugar Beet Technology 24 (1987): 80-100.

11. Ghonema M H. "Effect of plating dates and harvesting time on yield, yield components and quality of sugar beet (Beta vulgaris, L.)". Journal of Agricuture Science Mansoura University 23 (1998): 2971-2979.

12. Abd El-Gawad., et al. "Effect of some micronutrients on yield and quality of sugar beet (Beta vulgaris L.) Juice quality and chemical composition". Egyptian Journal of Agricultural Research 82.4 (2004): 1681-1691.

13. Abo El-Ghait R A M. "Evaluation of some sugar beet varieties under different environmental conditions". M.Sc. thesis, Faculty of Agriculture, El-Minufiya University, Egypt (1993).

14. Badawi M A. "Studies on sugar beet (Beta vulgaris L.)”. Ph.D. dissertation, Mansoura University, Egypt. (1985).

15. Badawi M A., et al. "Effect of planting dates and NPK fertilization on growth and yield of sugar beet (Beta vulgaris L.)". Journal of Agriculure Science Mansoura Univ 20 (1995): 26832689.

16. Kandil A A., et al. "Effect of planting dates, nitrogen levels and biofertilization treatments on: II- Yield, yield components and quality of sugar beet (Beta vulgaris L.)". Journal of Agricultural Science Mansoura University 27 (2002): 7257-7266.

17. Theurer J C. "Growth Patterns in Sugarbeet Production". Journal of American Society of Sugar Beet Technology 20 (1979): 343-367.

18. Hossain M F., et al. "Effect of sowing dates on growth and yield of tropical sugar beet". Inter Journal of Agronomy and Agricultural Research 7 (2015): 53-60.

19. Goto A M., et al. "Interaction between varietal characteristics and environmental conditions". Proceedings Japanese Society Sugar Beet Technologists 34 (1992): 64-69.

20. Kristek A., et al. "Economic value of sugar beet varieties in investigations in the Slavonia region". Poljoprivreda 3 (1997): 21-30.

21. El-Kassaby A T and Leilah AA. "Influence of plant density and nitrogen fertilizer levels on sugar beet productivity". Proceedings $5^{\text {th }}$ Conference Agronomy Zagazig 2 (1992): 954-962. 
22. Abdou M A. "Effect of planting dates, plant population and nitrogen fertilization on sugar beet productivity under newly reclaimed sandy soils". Ph.D. dissertation, Mansoura University, Egypt (2000).

23. Abo-Salama A M and El-Sayiad S I. "Studies on some sugar beet cultivars under Middle Egypt conditions: I- Response to planting and harvesting dates". Assiut Journal Agricultural Science 31 (2000): 137-159.

24. Leilah AA and Naser S M. "The contribution of sowing and harvesting dates on yield and quality of some sugar beet cultivars". $5^{\text {th }}$ Conference Agronomy, Zagazig University, Egypt (1992).

25. Fronek D., et al. "Results of field trails with sugar beet cultivars in 1995". Listy Cukrovarnicky Reparske 112 (1996): 3-10.

\section{Volume 3 Issue 10 October 2019}

(C) All rights are reserved by Gulzar Singh Sanghera., et al. 